\title{
Studying the Relationship between Financial Structure and Amount of Investment in Anzali Free Zone
}

\author{
Seyede Fateme Fazeli*1 \\ Mahbube Esmaili2 \\ Rahim Abedi ${ }^{3}$

\begin{abstract}
${ }^{4}$ Department of Business management, Faculty of Economic and Management, Urmia University, Urmia, Iran 2Department of Business management, Faculty of Economic and Management, Urmia University, Urmia, Iran ${ }^{3}$ Department of Business management, Faculty of Economic and Management, Urmia University, Urmia, Iran ${ }^{*}$ Corresponding author: Seyede Fateme Fazeli, E-mail: sf.fazeli@hotmail.com
\end{abstract}

\author{
Doi:10.5901/mjss.2015.v6n5p360
}

\section{Abstract}

The purpose of this study is to investigate the relationship between financial structure and amount of investment in the Anzali Free Zone. The intention of financial structure of an economic is institutional mechanisms for financing. Bank and capital market are the most important financing institutions in any economy. The research is conducted with the aim of applied research and used cross-correlation principle. The participants of the present study were 200 participants including staff and executives and investors in the Anzali Free Zone, which were selected only 130 participants with respect to the Morgan tables. Moreover, the results showed that there is a significant correlation coefficients and the relationship of the main hypothesis was also strong and straight. In addition, the result revealed that financial structure of bank-based was unsuccessful at attracting investment in the Anzali Free Zone.

Keywords: Financial Structure of bank, Financial Structure of capital, Investment, Free Zone.

\section{Introduction}

Investment plays a vital role in economic growth. In fact, the investment was a primary essential element in economic growth and development at the macro-level. The amount of economic growth and development depends on the accumulation and economic productivity and these two depends on investment process. Monetary and credit institutions and securities market, which are the main components of the financial markets, have an important role in the provision of financial assets and productivity. Monetary and credit institutions, which are mainly banks in Iran, play an important role in attracting bank deposits and attribution by using resource mobilization. In developing countries like Iran, banks are more sensitive in relation to the private sector due to the limitations of the activities of other financial institutions and financial investments. Other subsidiaries of financial market like capital market, due to the nature of their operations for economic activity has directly and closely with physical investment and therefore productivity and economic growth.

According to the role and the importance of the two pillars of the financial market, evaluating the performance of their economy can clarify many issues from the perspective of macroeconomic to use in solving problems and provide more resources for investment and resource allocation. Therefore, the aim of this study was to investigate the amount of investment in the Anzali Free Zone through Pearson correlation coefficient test to see which of element of financial structure have the most effective or not.

\section{Review of Literature}

In theoretical literature on financial economics, there are different views about the role of the financial structure of the economy of a country. In view of some economists banking system has better performance in economic than the marketbased system. But in contrast some one knows market-based system better. Other groups rejected the distinction between the economic performance of the two systems, agree that what is important is financial development and financial services which provided by the system. Empirically, there aren't evidence of the superiority of one system over the other two there. 
This topic depends on factors like legal system, level of financial development and level of development of the country. The financial structure of most countries has common law systems are towards a market-oriented. In contrast, the financial structure most countries with civil law systems tend to be bank-based system. Moreover, over time and with increasing levels of development, market share in the financing of many countries highly increased, so that in many cases leads to changing its financial structure from bank into market (Shahabuddin, 2013).

Financial Structure: The financial structure of the economy, are institutional mechanisms for financing. Banking and capital markets financing are two main institutions in every economy. Hence, the economies are so-called bank-oriented or market-oriented with respect to their dominant role in financing is on responsible of which of these two is an entity.

Some economists believed that financial structure has a decisive role in development and economic growth, whereas others believed that the financial structure and determines the form of financial services is the key issue at the level of financial development in an economy (Shahabuddin, 2013).

Free Zone: There are different definitions over the free zones, but common feature also exists between them; This common feature implies that, various limitations on in these areas such as customs and trade barriers, investment condition, foreign ownership, and etc. are lower in another area or even does not exist (Kia Karimi \& Moghaddam, 2013).

Investment: The process of converting funds into one or more assets that will be kept for some time in the future. These investments include investments in financial assets and securities trading, foreign investment in real estate and financial assets (Charles, 1943).

\subsection{How Markets and Financial Intermediaries affect the Performance and Economic Growth}

Markets and financial intermediaries affect the performance and economic growth and contribute to the welfare and prosperity, are conducted through impact on capital accumulation and technological innovation. Financial development, leads to savings mobilization and the allocation of investment projects with the highest returns.

With the allocation of capital investment projects and encouraging good corporate governance healthy, technology innovation and the growth rate of productivity will increase. As a result, direct criteria of economic performance including economic growth rate, the rate of capital accumulation, productivity growth rate, and the rate of technological innovation affected by financial development (Rahmani, 2010).

The relationship between financial sector development and economic growth has been widely debated among economists.

For example, we can mention to the studies of King and Levine (1994), Jappelli and Pagano (1994). There are views, which are complex relationship between financial sector development and economic growth

The followers of Oks (2001) believed that from perspectives of the development and economic growth, markets and financial intermediaries play an important key role in the development and economic growth.

They believed that the difference in the quantity and quality of services provided by financial institutions can be an important part of the difference in growth rates between countries. The studies of Odedokun (1996), Gregorio and Guidotti (1995), Levine and Zervos (1998) can be considered as Iran's economy.

In order to improve the financial markets, the World Bank in its annual report entitled "Financial Systems and Economic Growth", published in 1368, announced that creating an efficient financial sector and the free market is necessary for the sustained economic growth (Gelb, 1989).

In another research conducted by Levine and Demi Gok, they found interesting points about the country's financial structure. The results of their research include:

1. Banks, non-banks, and stock markets are larger, more active, and more efficient in richer countries. Financial systems, on average, are more developed in richer countries.

2. In higher income countries, stock market becomes more active and more efficient than the bank. Therefore, financial system tends to be marketed-based in richer countries.

3. Countries with a common law tradition, strong protection for shareholder rights, good accounting standards, low levels of corruption, and no explicit deposit insurance tend to be more market-based, even after controlling for income.

4. Countries with a French civil law tradition, poor accounting standards, heavily restricted banking systems, and high inflation generally tend to have underdeveloped financial systems, even after controlling for income.

\subsection{An overview of the financial system and financial intermediaries}

Financial intermediaries are firms that as brokers of the financial system for people create savings and loan deposits, 
equip their long-term loans and in this way increase liquidity and through the integration of a large number of loans, reduce the risk of small lenders. It should be noted that financial intermediaries for doing this, received interest or dividends and interest to the depositors that usually the amount of interest is over the paid.

Financial intermediaries can be divided into two categories depositor and no depositor. Financial intermediaries' depositor with funds achieved from deposits and other fund, pay direct loans to a lot of economic units and invest in securities. The main types of financial intermediaries' depositor include: Commercial banks, savings and loan institutions, savings banks and credit unions.

Financial intermediaries' no depositor, according to that financial interests of their, provide financial services but do not act as an intermediary means. The main types of financial intermediaries' no depositor include: Stock brokers, investment firms, pension funds, insurance companies, money market investment firms and financing companies.

According to the classification of financial intermediaries, Banks and credit institutions can name as non-bank financial intermediaries's depositor and exchange, insurance companies, pension funds investment firms can be considered as financial intermediaries' no depositor. But Iran's financial system and financial intermediaries can be mainly introduced in the banking system and stock exchange.

Therefore, due to limited activity in the stock exchange and given that the banking system in Iran is one of the main buyers of shares in the stock market, only banks named as financial intermediaries in Iran (Esfahani et al, 2009).

Iran's financial system like other countries, consist of money and capital market. The money market include: Banking System, non-bank credit institutions, and is like traditional money. It's capital stock, activities through the exchange which commodity exchanges and OTC market added to them in the last few years. But unfortunately, financial markets have not found its appropriate position in the economy. This means that the markets are not able collect and equip financial resources to meet the needs of the real sector and on the other allocate to different economic sectors. The main witness claim In contrast to short-term money markets is lack of long-term capital markets. Money market dominance and banks-oriented financial system of official statistics are readily understandable from Official statistics's perspective (Abu Ja'fari, 2011).

\subsection{Factors Affecting Investment in Free Zones}

Table 1 demonstrated researches that conducted for identifying factors affecting investment in the free zones.

Table 1. Research conducted on factors affecting investment in the country

\begin{tabular}{|c|c|c|}
\hline Scholar-year & Work carried out & Variables \\
\hline Shakeri and Salimi (2006) & $\begin{array}{l}\text { Factors affecting investment in the free zone in CHABAHAR } \\
\text { and Prioritizing them by using AHP Mathematical } \\
\text { techniques }\end{array}$ & $\begin{array}{l}\text { Lack of appropriate executive agencies } 32 \% \\
\text { Failure of regulation } 25 \% \\
\text { Adverse effect of government policy } 23 \% \\
\text { Absence and lack of infrastructure } 2 \% \\
\text { Administrative and policy requirements }\end{array}$ \\
\hline Rahnavard (2010) & $\begin{array}{l}\text { Factors affecting the operation of the free zones industrial } \\
\text { and commercial of Iran }\end{array}$ & $\begin{array}{l}\text { Environmental factors } \\
\text { Clarification of the rules and regulations } \\
\text { Strategic orientation } \\
\text { Financing mechanisms }\end{array}$ \\
\hline Nahidi et al (2011) & $\begin{array}{l}\text { Factors affecting investment in Aras free zone And } \\
\text { prioritizing them based on hierarchical analysis process }\end{array}$ & $\begin{array}{l}\text { The impact of government policy } 9 / 12 \% \\
\text { Lack of a strong executive management } 19 / 11 \% \\
\text { Lack of proper positioning } 60 / 98 \% \\
\text { Lack of infrastructure }\end{array}$ \\
\hline Karimi Kia and moghaddam (2012) & Factors Investment in Arvand Free Zones & $\begin{array}{l}\text { Disinvestment organizations and public institutions } \\
\text { Lack of appropriate legal } \\
\text { Failure to properly locate }\end{array}$ \\
\hline
\end{tabular}

Finally, one of the main obstacles to the development of free zones is lack of adequate resources for investing in infrastructure that leading to a tendency toward specific areas for financing imports. For example, the total income of 1400 billion rials in Iran Free Trade Zones, during the period 1993 to 1997 that 53 percent of which is related to the toll and goods, Nearly 777 billion has been spent on infrastructure.

Despite abundant natural resources and economic potential and prospects of the Free Zones, which put this indicator in the category of outstanding regional and global, unfortunately because of governance at state over the past few years and today, the position of this area has become a part of development due to the entry of domestic and foreign investment and rejection investment. 
More than 15 years have passed since the launch free zones. Despite this years and the doing costs, yet necessary infrastructure and buildings to define a model for development and organized accordance with international standards, are not available. This topic beside the unclear management and mismatch capabilities of law enforcement agents in the free zones which is due to lack of experience and lack of belief extensibility sustainable economic, these factors have caused even in talks with foreign and domestic investors and less cautious and intelligent respect for the applicant's motivation to invest in areas that fall free.

Looking at the statistics most productive economic activities in the free zones like export products, builds on trade and transit of goods, rates increase productivity and income from growth services and re-export facilities and rates that affected from sustainable development and continuous investment shows backward development indicators in this area (Moghaddasi, 2011).

\subsection{Conceptual model}

Figure 1 shows the conceptual model.

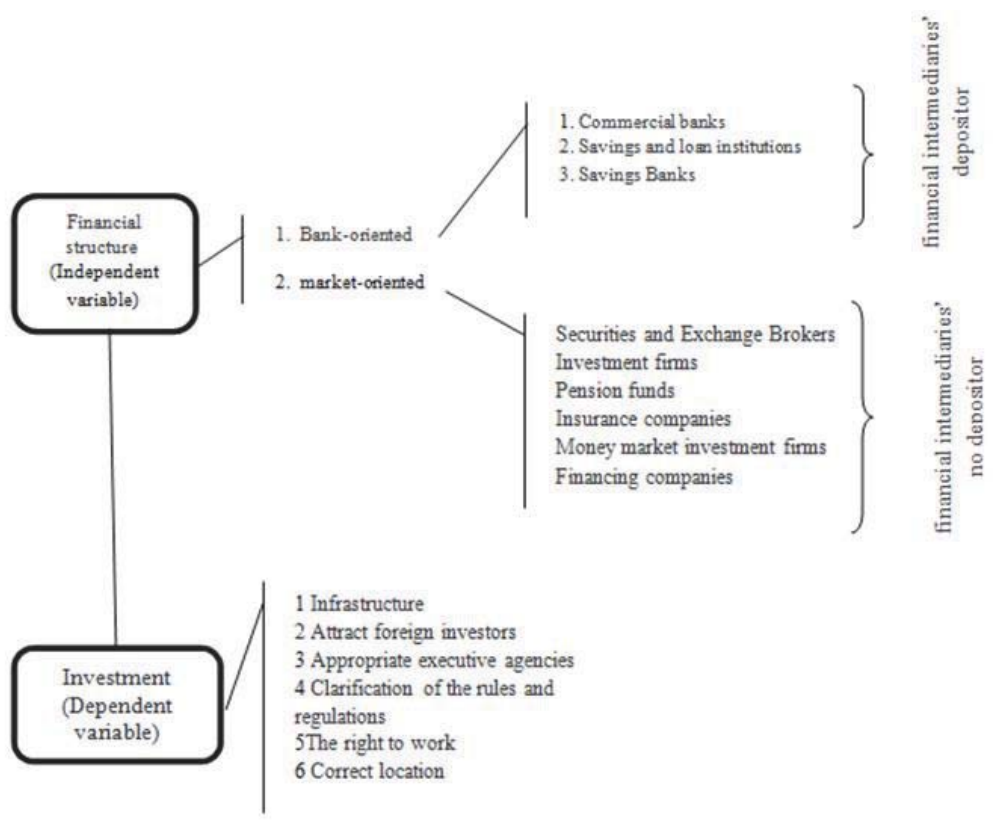

Figure 1. Conceptual model

\section{Methodology}

This study was completely descriptive. With respect to the relationship between financial structure and the amount of investment in research, the analysis of data was correlation, which was calculated by SPSS software. Therefore, the following hypothesize as follows:

The main hypothesis: There is a significant relationship between financial structure and the amount of investment in Anzali free zone.

The first sub-hypothesis: There is a significant relationship between the financial structure of the market and the amount of investment in Anzali free zone.

The second sub-hypothesis: There is a significant relationship between bank-based and financial structure in Anzali free zone.

The inferential analysis of data started with the data normalization. To test the hypotheses of the study, the sample data were analyzed using Pearson's correlation coefficient and to ensure the results correlation coefficients for each 
hypothesis test was used to assist.

This research was conducted in the years between 2012 and 2013 in Anzali Free Zone. The sample research consists of contract staff, official, experts, and executives of Anzali Free Zone, investors and others are about 200 members. The sample size was considered 130 participants with respect to the table's Morgan. By using simple random sampling, the researchers can implement the study. This is one of the simplest methods, which are their subjects are available.

Information and data required for achieve theoretical research is gathered in literature review and benefit from the experiences of other researchers and experts.

The researchers used questionnaire as the primary means for gathering data collection for information related to the investment and financial intermediaries' depositor and financial intermediaries' no depositor. In addition, the researchers considered the indicators to measure the variables are listed in Table 2:

Table 2. The main and auxiliary variables and their indicators

\begin{tabular}{|lll|}
\hline The main variable & Variable Sub & Indicators \\
\hline Financial structure & Bank-oriented & Commercial banks, Savings and loan institutions, Savings and loan institutions, Credit unions \\
& Capital-oriented & $\begin{array}{l}\text { Securities and Exchange, Investment firms, Pension funds, Insurance companies, Money } \\
\text { market investment firms, Financing companies }\end{array}$ \\
\hline
\end{tabular}

\section{Results and Discussion}

Independent variable research means that financial structure with the help of questionnaire and a review of documents, documents, processes, and interviews were evaluated. This present study suggests a tendency to bank-based free Zone's financial structure. In this structure, the status of financial intermediaries's depositor has average above average.

According to the results of a questionnaire on factors influencing investment, we can observe that factor affecting the investment is weak in Anzali Free Zone. However, the criteria of these executive agencies have higher average than the other components. Hence, the foreign investors and plan are appropriate.

The inferential analysis of data started with using the normality of the data. The assumption of normality of data was examined with the using of the Kolmogorov-Smirnov.

Table 3. Kolmogorov-Smirnov test results

\begin{tabular}{|lcc|}
\hline Variables & Significantly level & Assumption of normality \\
\hline Commercial banks & $0 / 147$ & Normal \\
Savings and loan institutions & $0 / 107$ & Normal \\
Savings Banks & $0 / 254$ & Normal \\
Credit unions & $0 / 053$ & Normal \\
Financial structure Bank-oriented & $0 / 002$ & Normal \\
Securities and Exchange Brokers & $0 / 104$ & Normal \\
Investment firms & $0 / 142$ & Normal \\
Pension funds & $0 / 322$ & Normal \\
Insurance companies & $0 / 107$ & Normal \\
Money market investment firms & $0 / 045$ & Normal \\
Financing companies & $0 / 005$ & Normal \\
Market-oriented financial structure & $0 / 105$ & Normal \\
\hline
\end{tabular}

According to Table 3, assuming normality of the distributions accepted to illustrate the relationships between variables Pearson correlation test was used.

To test the hypotheses of the study, first, the data sample is evaluated using calculating the Pearson correlation coefficient and to ensure the results, the correlation coefficients for each hypothesis was used to help test was used and finally, the hypothesis was rank based on correlation coefficient. 
Table 4. The results of correlation between variables

\begin{tabular}{|cccll|}
\hline $\begin{array}{c}\text { Financial structure } \\
\text { Bank-oriented }\end{array}$ & $\begin{array}{c}\text { Market-oriented financial } \\
\text { structure }\end{array}$ & $\begin{array}{l}\text { Financial } \\
\text { structure }\end{array}$ & \\
\hline$-0 / 176$ & $0 / 578$ & $0 / 560$ & The correlation coefficient Pearson & \\
$0 / 000$ & $0 / 000$ & $0 / 000$ & Two-sided significance level & Amount of investment \\
130 & 130 & 130 & Count & \\
\hline
\end{tabular}

According to the results in Table 4, there is a significant correlation coefficient in each hypothesis with possibility of 0.95 at significance level.

The results confirmed all researches of hypotheses. However, the main hypothesis of the relationship in the first sub-hypothesis was strong and direct and the second sub-hypothesis was low and reverse.

Table 5. The results of the ranking variables

\begin{tabular}{|lccccc|}
\hline Hypothesis & $\mathbf{R}$ & Rank r & $\mathbf{R}^{2}$ & Percent change & Ranking r2 \\
\hline The main hypothesis & $0 / 560$ & 2 & $0 / 313$ & $30 / 31 \%$ & 2 \\
Sub-hypothesis 1 & $0 / 578$ & 1 & $0 / 334$ & $40 / 33 \%$ & 1 \\
Sub-hypothesis 2 & $-0 / 176$ & 3 & $0 / 030$ & $3 \%$ & 3 \\
\hline
\end{tabular}

According to Table 5, the first sub-hypothesis has first ranking in terms of intensity correlation. The main hypothesis is in the second ranking, and the second sub-hypothesis is third ranking in different orientation.

\section{Conclusion}

According to the results of the research hypothesis, there is a significant relationship between financial structure and the amount of funding was approved by $95 \%$.

The results showed that there is a direct relationship between these two variables. As a result, the financial structure of the investment amount is effective in Anzali Free Zone. In addition, one of the reasons for the decline in investment in this area is due to financial structure inappropriate.

The first sub-hypothesis of research showed a direct correlation between market-based financial system and the investment in Anzali Free Zone. In other words, one reason for the low economic growth in Iran depends on how the investment process. In this regard, the Anzali free zone is not an exception and can be a reason of the low level of investment in this area. In addition, low levels of investment in the stock exchange and OTC can mention as causes of decreases in investment in the Anzali Free Zone. The second sub-hypothesis showed weak negative correlation between bank-based and financial structure and the amount of investment in the Anzali Free Zone. Since the financial structure of the Anzali free zone tends to be bank-based, the results show the structure of investment in Anzali free zone has not been effective.

In line with these, the results suggest that government with integrity and genuine commitment to engage the private sector, the planning and policy free zones economic with respect to the great market orientation, assigned to the department of commerce, and investment leading to sustainable economic development of the region and country in order to focus in the area of senior management, systematic structuring, and policies relating to them in line with the objectives to be achieved through this assignment.

\section{References}

Abu Ja'fari, R. (2011). Financial institution-building necessary to the development of new businesses. Fourth International Conference on Management of Technology, organizer: Association of Management of Technology.

Charles P. J. (1943). Investments: analysis and management. New York: Chichester, Wiley.

De Gregorio, J. and Guidotti, P.E. (1995). Financial development and economic growth. IMF Working Paper, World Development. 23(3): 433-448.

Esfahani, R. Barzani, M. and Karahrud, R. (2009). Intermediaries of financial impact on economic growth. Journal of Humanities and Social Sciences, Economic Sciences, 8(28): 13-30.

Gelb, A, H. 1989. Financial policies, growth, and efficiency. world bank. wps: 0202, Vol.1, pp 1-39.

Jappelli, T. and Pagano, M., (1994). Saving, Growth, and Liquidity Constraints. Quarterly Journal of Economics, 109(1): 83-109. 
Kia Karimi, J. and Moghaddam, M. (2013). Assessment of the factors attract investment in Arvand Free Zone. Economic Journal, vol.6-7, pp 5-28.

King Robert, G. and Levine, R., (1993). Finance and Growth: Schumpeter Might Be Right. Quarterly Journal of Economics. 108(3): 717737.

Levine, R. and Zervos, S. (1998). Stock market, banks and economic growth. American Economic Review, 88, (3): 537-358.

Moghaddasi, A., (2011). Free Zones principles, concepts, functions and Solutions . http://www.mgtsolution.com/olib/224306264.aspx

Nahidi. M. Azar kasb. A. Mohamad nejad. J. and Alimohamadi. E. (2012). Factors affecting attract investment in Aras and prioritizing them based on hierarchical analysis process AHP. Quarterly financial engineering and management of securities. No. 9, pp. 155178.

Odedokun, M. (1996). Alternative econometric approaches for analyzing the role of the financial sector in economic growth: Time series evidence from LDC. Journal of Development Economics, 50(1): 119-146.

Oks, A. (2001). Efficiency of the Financial Intermediaries and Economic Growth in CEEC. SSRN Electronic Journal. No. 562. doi:10.2139/ssrn.419821

Rahmani, A. (2010). The need to improve the business climate. Quarterly Journal Monetary Economics, No. 1. pp. 145- 175.

Rahnavard, F. (2011). Factors affecting the performance of Free Trade- Industrial Zones. Quarterly Process Management and Development, 23(2): 45-59.

Shahabuddin, H. (2013). Financial structure. Quarterly Journal of New Economy, vol.136, pp 205-207.

Shakeri, A., Salimi, F. (2006). Factors Affecting attract investment in Chabahar and prioritize them using a mathematical technique AHP. Journal of Economic, No. 6, pp 95-130. 